MANAJEMEN PEMBERDAYAAN ZAKAT DAN MANFAATNYA DI INDONESIA

Diajukan untuk memenuhi tugas mata kuliah Fiqh Zakat dan Wakaf

Dosen Pengampu:

Ust. Samsul Arifai, S.A.B.,M.A.

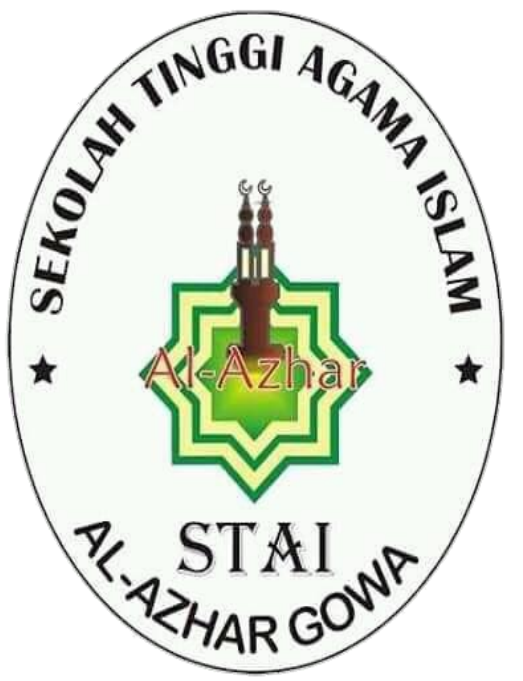

Oleh:

Nama: Enny Winarni

NIM : 1122020012

EKONOMI SYARIAH

STAI AL-AZHAR GOWA 


\section{KATA PENGANTAR}

Syukur Alhamdulillah senantiasa kami panjatkan kehadirat Allah Swt. yang telah melimpahkan rahmat dan karunia-Nya sehingga kami dapat menyelesaikan makalah ini guna memenuhi tugas kami sebagai mahasiswa untuk mata kuliah Fiqh Zakat dan Wakaf dengan judul “ Manajemen Pemberdayaan Zakat dan Manfaatnya di Indonesia".

Kami menyadari bahwa dalam penulisan makalah ini tidak terlepas dari bantuan dan saran dari teman-teman sehingga makalah ini dapat terselesaikan dengan waktu yang tepat. Kami juga menyadari bahwa penulisan makalah ini masih jauh dari kata sempurna dikarenakan terbatasnya pengalaman dan ilmu pengetahuan yang kami miliki. Oleh karenanya, kami mengharapkan segala bentuk saran serta masukan bahkan kritik yang membangun dari berbagai pihak. Akhirnya kami berharap semoga makalah ini dapat memberikan manfaat bagi perkembangan ilmu pengetahuan dan pendidikan.

Makassar, 12 November 2021 


\section{DAFTAR ISI}

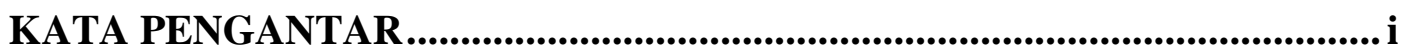

DAFTAR ISI .................................................................................................................. ii

\section{BAB I PENDAHULUAN}

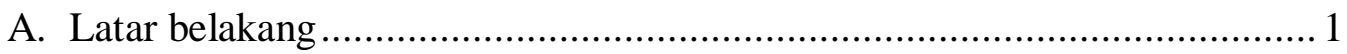

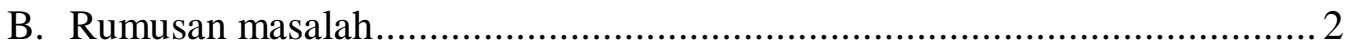

\section{BAB II PEMBAHASAN}

A. Manajemen pemberdayaan zakat .............................................................. 3

1. Pengertian manajemen .................................................................... 3

2. Sistem pengelolaan dan pemberdayaan zakat ....................................... 4

3. Pemberdayaan dana zakat di LAZ ..................................................... 5

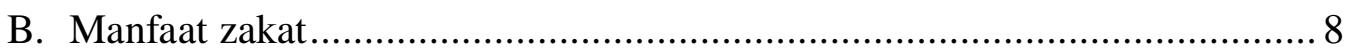

1. Manfaat zakat dari segi agama ........................................................ 8

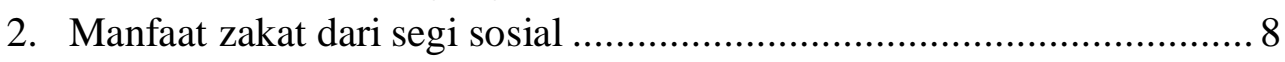

3. Manfaat zakat dari segi finansial ...................................................... 9

\section{BAB III PENUTUP}

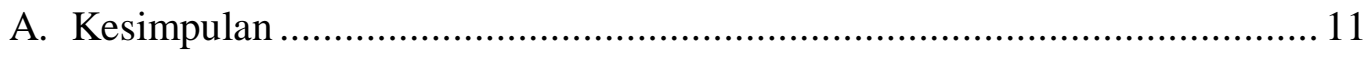

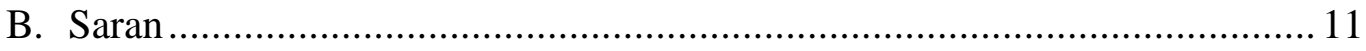

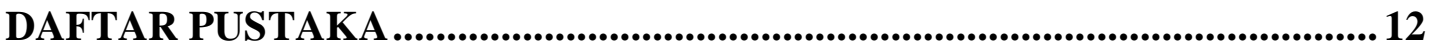




\section{BAB I \\ PENDAHULUAN}

A. Latar belakang

${ }^{1}$ Zakat sebagai rukun Islam merupakan kewajibab bagi setiap umat muslim di Indonesia yang mampu untuk membayarnya dan diperuntukkan kepada mereka yang berhak menerimanya. Dengan pengelolaan yang baik, zakat merupakan sumber dana potensial yang bisa dimanfaatkan untuk mencapai kesejahteraan umum di Indonesia bagi seluruh masyarakat. Pengelolaan zakat tidak cukup dengan niat yang baik saja, melainkan harus didasarkan pada yang berhak mengelola zakat tersebut dengan tata kelola yang baik. Peran Amil zakat dan juga manajemen pengelolaan zakat yang profesional diharapkan mampu memanfaatkan potensional zakat yang belum maksimal di Indonesia. Amil zakat ditunjuk oleh pemerintah untuk melaksanakan pengelolaan zakat secara nasional yang diberi nama Badan Amil Zakat Nasional (BAZNAS) yang mempunyai kewajiban dalam rangka perencanaan, pengorganisasian, pelaksanaan, dan pengawasan terhadap pengumpulan dan pendistribusian serta pendayagunaan atau pemanfaatan zakat (Kementrian Agama RI,2012).

${ }^{2}$ Allah telah memberikan ilmu pengetahuan tentang zakat kepada kita semua tentang bagaimana cara kita mengelola dana zakat dengan baik sesuai syariat sehingga dapat mensejahterakan masyarakat. Menurut aturan, baik yang tercantum dalam Al-Quran dan As-Sunnah, yang kemudian yang harus bertanggung jawab atas kesejahteraan rakyat adalah pemerintah berperan sebagai Khalifah Allah. Lembaga atau badan yang berhak mengelola zakat adalah pemerintah ataupun penguasa. Hal ini sesuai dengan Quran Surah AtTaubah ayat 103 yang berbunyi :

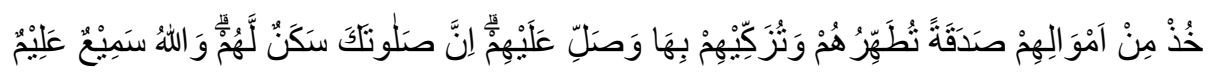

Yang artinya : "Ambillah zakat dari sebagian harta mereka, dengan zakat itu kamu membersihkan dan mensucikan mereka, dan berdoalah untuk mereka.

\footnotetext{
${ }^{1}$ Irsad Andriyanto, 'Pemberdayaan Zakat Dalam Meningkatkan Kesejahteraan Umat', Ziswaf, 1.2 (2014), 1-22 <http://journal.stainkudus.ac.id/index.php/Ziswaf/article/view/1485>.

${ }^{2}$ Y Sudrajat and A M I Jaya, 'Pemanfaatan Dana Zakat Oleh Badan Amil Zakat Nasional Dalam Pemberdayaan Masyarakat Miskin Di Kabupaten Bantaeng Provinsi ...', J-3P (Jurnal Pembangunan ..., 2019, 127-38 <http://ejournal.ipdn.ac.id/JPDPP/article/view/857>.
} 
Sesungguhnya doa kamu itu (menjadi) ketentraman jiwa bagi mereka. Dan Allah Maha Mendengar lagi Maha Mengetahui."

Kemudian sesuai dengan hadits-hadits nabi baik yang berupa ucapan maupun yang berupa perbuatan dan kebijaksanaan para Khulafa Rasyidin (Permono,2005)

B. Rumusan Masalah

1. Bagaimana manajemen pemberdayaan zakat di Indonesia?

2. Apa manfaat zakat di Indonesia? 


\section{BAB II}

\section{PEMBAHASAN}

\section{A. Manajemen pemberdayaan zakat}

1. Pengertian manajemen

${ }^{3}$ Secara umum pengertian strategi adalah cara untuk mendapatkan kemenangan atau mecapai tujuan. Strategi pada dasarnya merupakan seni dan ilmu menggunakan dan mengembangkan kekuatan untuk mencapai tujuan yang telah ditetapkan sebelumnya. Sama halnya dengan strategi pemberdayaan zakat. Sebelumnya kita sudah menetapkan suatu tujuan yaitu bagaimana memberdayakan zakat. Maka dari itu kita harus mencari cara bagaimana supaya kita dapat menciptakan suatu cara yang dapat diimplementasikan dalam pemberdayaan zakat. Tentunya dalam penciptaan strategi ini harus sesuai dengan kemampuan yang kita miliki berdasarkan sumber daya yang ada.

Manajemen pemberdayaan zakat atau pendayagunaan zakat yaitu menyalurkan dana zakat yang disalurkan kepada orang yang berhak menerima dana zakat yang telah diatur dan di tentukan dalam syariat Islam. Maka dari itu dapat dikatakan bahwa dana zakat disalurkan kepada penerima zakat secara konsumtif maupun produktif. Pemberdayaan merupakan kegiatan atau usaha yang dilakukan untuk mendayagunakan dana zakat agar mampu mendatangkan hasil atau manfaat dengan cara menyalurkan dana zakat kepada mustahiq secara produktif dengan tujuan agar zakat mendatangkan manfaat dan bisa merubah mustahiq (penerima zakat) menjadi mudzakki (pemberi zakat). Pendayagunaan zakat disalurkan kepada orang yang berhak menerimanya, golongan-golongan yang berhak menerima zakat ialah fakir, miskin, amil, muallaf, riqab, gharim, fisabilillah, dan ibnu Sabil. Hal ini tercantum dalam Firman Allah dalam Quran Surah At-Taubah ayat 60 yang berbunyi :

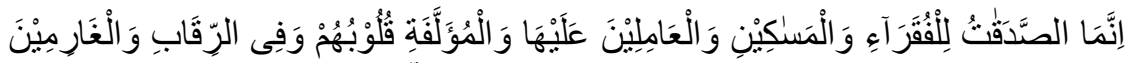

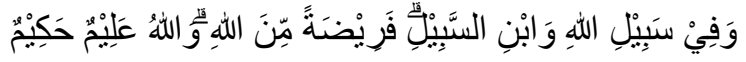

\footnotetext{
${ }^{3}$ Sudrajat and Jaya.
} 
Yang artinya : " Sesungguhnya zakat itu hanyalah untuk orang-orang fakir, orang miskin, amil zakat, yang dilunakkan hatinya (muallaf), untuk (memerdekakan) hamba sahaya, untuk (membebaskan) orang yang berutang, untuk jalan Allah (fisabilillah) dan untuk orang yang sedang dalam perjalanan, sebagai kewajiban dari Allah. Allah Maha Mengetahui, Mahabijaksana."

2. Sistem pemberdayaan dan pengelolaan zakat

${ }^{4}$ Dalam pengelolaan zakat terdapat beberapa prinsip-prinsip yang harus diikuti dan ditaati agar pengelolaan dan pemberdayaan zakat dapat berhasil sesuai yang diharapkan, di antaranya :

1) Prinsip Keterbukaan, artinya dalam pengelolaan zakat hendaknya dilakukan secara terbuka dan diketahui oleh masyarakat umum. Tujuannya agar masyarakat bisa mengetahui bagaimana pemberdayaan zakat yang sesuai dalam syariat Islam tanpa adanya pelaku kecurangan didalamnya.

2) Prinsip Sukarela, artinya bahwa dalam pemungutan atau pengumpulan zakat hendaknya senantiasa berdasarkan pada prisip sukarela dari umat islam yang menyerahkan harta zakatnya tanpa ada unsur pemaksaan atau cara-cara yang dianggap sebagai suatu pemaksaan. Artinya disini dimaksudkan bahwa orang yang mengeluarkan zakat benar-benar ikhlas dalam mengeluarkan zakatnya dan telah mengetahui tujuan dikeluarkannya zakat tersebut, baik berupa zakat fitrah maupun zakat maal.

3) Prinsip Keterpaduan, artinya dalam menjalankan tugas dan fungsinya harus dilakukan secara terpadu diantara komponenkomponen yang lainnya. Prinsip keterpaduan sangat penting juga dalam konteks zakat agar siapapun yang terlibat dalam pengeluaran ataupun pengumpulan zakat harus mengetahui dan menjalankan tugasnya masing-masing dan tentunya memperhatikan aturan-aturan yang telah diatur dalam pemberdayaan zakat.

4) Prinsip Profesionalisme, artinya dalam pengelolaan zakat harus dilakukan oleh mereka yang ahli di bidangnya, baik dalam

\footnotetext{
${ }^{4}$ Anwar Sadat Harahap and Dalyanto, 'Kajian Hukum Islam Terhadap Manfaat Zakat Dalam Pengembangan Ekonomi Masyarakat', Amaliah: Jurnal Pengabdian Kepada Masyarakat, 4.1 (2020), 99-105 <https://doi.org/10.32696/ajpkm.v4i1.402>.
} 
administrasi, keuangan, dan sebagainya. Dalam pengelolaan zakat dibutuhkan orang yang kompeten dibidangnya masing-masing sehingga tidak terjadi kesalahan dan tidak ada kendala dalam memberdayakan zakat tersebut.

5) Prinsip Kemandirian, prinsip ini sebenarnya merupakan kelanjutan dari prinsip prefesionalisme, maka diharapkan lembagalembaga pengelola zakat dapat mandiri dan mampu melaksanakan tugas dan fungsinya tanpa perlu menunggu bantuan dari pihak lain.

3. Pemberdayaan dana zakat di LAZ

1) ${ }^{5}$ Rumah sehat dengan visi menjadi model pelayanan dan pemberdayaan kesehatan khususnya masyarakat dhuafa yang berstandar nasional. Rumah sehat BAZNAS merupakan pelayanan kesehatan untuk mustahik atau untuk di daerah yang terkena bencana. Jenisnya adalah dengan konsep pelayanan di dalam ruangan dan di luar ruangan. Model pelayanan dalam ruangan seperti adanya dokter umum, UGD, dokter spesialis, konsultasi psikologi, unit farmasi, ambulance, ruang rawat inap, dan khitanan masal. Sedangkan pelayanan di luar ruangan seperti pemberian edukasi kesehatan kepada masyarakat dan pengobatan untuk kaum dhuafa.

2) Microfinance adalah suatu lembaga yang membantu dalam pembiayaan produktif kepada orang yang berhak (mustahik) berdasarkan prinsip non for profit dengan maksud melakukan pengembangan wirausaha. Modal yang yang diberikan oleh lembaga microfinance dalam pengembangan wirausaha merupakan faktor yang sangat penting. Jika hanya mengandalkan dari modal mustahik tentu kecil dan usaha akan lambat berjalannya. Sebaliknya jika permodalan ditopang oleh perbankan tentu akan sulit karena dalam administrasinya akan menemui kendala. Oleh karena itu demi meningkatkan perekonomian lebih jauhnya keadilan sosial, akses untuk mendapatkan pendapatan dipermudah dengan adanya program dari BAZNAS. Adapun agar mendapatkan bantuan maka mustahik harus mempunyai rekening bank dan surat keterangan usaha minimal dari kelurahan serta usahanya sudah ada kurang lebih selama satu tahun.

\footnotetext{
${ }^{5}$ Andriyanto.
} 
Salah satu lembaga amil zakat hasil pembentukan masyarakat yaitu Dompet Dhuafa, Yayasan ini berdiri pada tahun 1994 dan dikukuhkan pada tahun 2001 sebagai lembaga amil zakat dengan beberapa program pemberdayaan zakat. Pemberdayaan dana zakat tidak lagi bersifat konsumtif namun lebih produktif. Seperti program pemberdayaan dana zakat divisi ekonomi. Tujuannya adalah supaya tercipta lahan pekerjaan baru. Dengan adanya penciptaan lahan pekerjaan baru, para mustahik yang mendapat dana zakat kemudian akan bisa mendayagunakan dana zakat tersebut untuk kelangsungan hidupnya dan juga agar mustahik tersebut kemudian bisa menjadi mudzakki karena telah mendapat penghasilan dari dana zakat tersebut sehingga dengan keadaan seperti ini maka kemiskinan dan kemelaratan yang ada di masyarakat khususnya di Indonesia bisa berkurang jumlahnya. Contohnya Dompet Dhuafa Jawa Barat meluncurkan program pendaki (pendampingan pedagang keliling). Program ini merupakan pemberdayaan dana zakat yang diberikan kepada para pedagang kaki lima dengan bantuan gerobak jualan agar gerobak tersebut menarik dan higienis serta menjadikan sumber pendapatan. Untuk fasilitas pendaki ini tentu melalui seleksi atas pendapatan pedagang dan keadaan gerobak, disini kita akan mengetahui bagaimana kemudian para pedagang mendapatkan penghasilan dari gerobak zakat yang didapatkannya.

Pemberdayaan dana zakat yang lain adalah Lembaga Amil Zakat yang lain seperti Dompet Peduli Umat Daarut Tauhid yang bertindak sebagai lembaga amil zakat nasional (LAZNAS) berdasarkan SK Menteri Agama no. 410, mempunyai program pemberdayaan dana zakat infak dan sedekah. Program Beasiswaku adalah program pemberdayaan dana ZIS untuk fakir miskin yang mempunyai potensi dalam pendidikan namun terbentur dengan biaya pendidikan. Program Beasiswaku hadir dari mulai tingkat TK/PAUD, SD, SMP, SMA, dan Perguruan tinggi.

4. Pemberdayaan zakat di perusahan sebagai saham

Ada beberapa tantangan yang dihadapi sebagai mudzakki di perusahan antara lain sebagai berikut.

1) Pelanggar tidak akan mendapatkan sanksi. Maksudnya para wajib zakat yang tidak membayar zakat tidak dikenakan sanksi dan tidak ada fatwa yang mengeluarkan sanksi tersebut.

2) Perusahaan dihadapkan pada potensi pembayaran ganda dengan pajak (double payment). 
3) Ketiga, Potensi khlafiyah wajib zakat perusahaan sebagai muzaki. Syarat wajib zakat diantaranya adalah beragama Islam. Perusahaan sebagai badan usaha yang dikelola perorangan identic dengan wajib zakat perorangan karena keuntungan perusahaan adalah milik perorangan.

4) Metode dan basis penghitungan zakat juga menjadi perdebatan

Menurut (Mukhlis \& Beik, 2018)pemahaman agama juga menjadi tolak ukur keengganan menjadi muzakki, seharusnya semakin baik pemahaman agama seseorang membuat ia semakin termotivasi untuk menunaikan zakat. Karena ia sudah mengerti bahwa membayar zakat adalah sebuah kewajiban, ia mengetahui balasanbalasan kebaikan yang akan dia dapatkan jika membayar zakat, dan mengetahui hukuman-hukuman bagi mereka yang tidak mau membayar zakat padahal mereka mampu

Perusahaan ${ }^{6}$ (Hadi, 2016)dihadapakan pada kewajiban CSR dan Zakat, keduanya memiliki kewajiban yang sama terhadap aturan negara. Namun beda dari segi kewajiban agama. CSR adalah pertanggungjawaban sosial sedangkan zakat pertanggungjawaban terhadap Allah. Jika perusahaan membayar keduanya maka akan berpengaruh terhadap pendapatan. Maksudnya mudzakki yang telah membayar zakat semestinya tidak membayar pajak ataupun sebaliknya. Karena pendapatan pada perusahaan akan berpengaruh atau bisa saja menurun.

Strategi yang digunakan dalam pemberdayaan zakat diantaranya adalah antara lain sebagai berikut.

1. Meningkatkan perekonomian di masyarakat secara langsung dengan memberikan modal usaha kepada mustahik sehingga menggunakan dana zakat tersebut untuk menghasilkan penghasilan yang kemudian bisa mengurangi tingkat kemiskinan di Indonesia.

2. Melakukan peningkatan perekonomian dengan memberikan modal usaha untuk pengembangan dan pelatihan skiil dan keterampilan bagi para mustahik untuk mengembangkannya menjadi sebuah penghasilan.

${ }^{6}$ Ruslang Ruslang, Samsul Samsul, and Mujetaba Mustafa, 'Komitmen Perusahaan Menjadi Muzakki', Al-Azhar Journal of Islamic Economics, 2.1 (2020), 25-35 <https://doi.org/10.37146/ajie.v2i1.26>. 


\section{Meningkatkan perekonomian dengan membuka lapangan pekerjaan bagi para mustahik}

\section{B. Manfaat zakat}

1. Manfaat zakat dari segi agama diantaranya sebagai berikut.

a. Menyempurnakan Iman

Berzakat kepada mereka yang membutuhkan merupakan salah satu pilar agama Islam. Setiap muslim pasti berusaha melaksanakan amalan ini dengan tujuan melengkapi kewajiban yang diamanatkan agamanya.

b. Bukti Keimanan dan Ketaatan

Manusia membutuhkan dan mencintai uang sebagai sesuatu yang bisa dimiliki. Oleh karena itu, terkadang orang tidak rela melepaskan apa yang dia cintai tanpa imbalan apapun.Dengan membayar zakat, atau bisa disebut sedekah, kamu sudah menunjukkan keimananmu kepada Allah SWT. Sebab, dengan berzakat kamu tidak mengharapkan imbalan duniawi melainkan ketenangan hati dan pahala dari Allah SWT.

c. Membersihkan Hati dan Diri

Dengan membayar zakat, muslim telah masuk ke dalam kelompok orang dermawan dan memisahkan diri dari kelompok orang-orang kikir. Alasannya, jika seseorang sudah terbiasa memberi dalam bentuk apapun, seperti pengetahuan, uang, atau kebaikan, dirinya akan merasa lebih "lengkap" ketika telah memberikan sesuatu yang berarti untuk orang lain.

d. Menenangkan Hati

Berzakat melatih umat Muslim untuk ikhlas. Jika dilakukan dengan ikhlas dan tanpa paksaan, zakat bermanfaat melatih kita menjadi pribadi yang ikhlas dan tulus melakukan kebajikan bagi orang lain. Inilah hikmah zakat yang akan membawa banyak keselamatan untukmu.

e. Mencapai Keimanan yang Sempurna

Rasulullah SAW bersabda, "Salah seorang di antara kalian tidaklah beriman (dengan iman sempurna) sampai ia mencintai saudaranya sebagaimana ia mencintai dirinya sendiri." (HR. Bukhari: 13)

2. Manfaat zakat dari segi sosial antara lain sebagai berikut.

a. Terbiasa Membantu Sesama

Manfaat zakat selanjutnya adalah menjadikan umat Islam sebagai satu keluarga besar, yang saling membantu satu sama lain.Empati saat berzakat menimbulkan perasaan bahwa kita memiliki saudara sesama yang harus diperlakukan dengan baik, sebagaimana kebaikan yang telah Allah SWT berikan kepada kita. Allah SWT berfirman (Al-Qur'an 28: 77): "Dan 
berbuat baiklah (kepada orang lain), sebagaimana Allah telah berbuat baik kepadamu."

b. Menghilangkan Rasa Iri dan Prasangka

Beberapa orang memang memiliki nasib kurang beruntung dibandingkan yang lainnya, maka dari itu tidak ada salahnya jika kamu membantu mereka yang kurang beruntung.Dengan begitu, kamu akan mengurangi rasa iri atau prasangka buruk yang ada pada mereka. Mereka akan berpikir bahwa orang-orang yang memiliki kekayaan merupakan saudara yang mau membantu di masa yang sulit, dan bukan orang yang sombong atau tidak peduli sekitar.

c. Merendahkan Hati

Zakat merupakan kewajiban yang harus dilakukan, tetapi bukan secara terang-terangan. Sesungguhnya Allah SWT tidak menyukai hambanya yang berhati tinggi. Seperti apa yang difirmankan oleh Rasulullah SAW: "Amal yang diberikan secara rahasia dapat memadamkan kemurkaan Allah SWT.” (Dalam HR. At-Tirmidzi dan Ibnu Hiban).

3. Manfaat zakat dari segi finansial

a. Meningkatkan Rezeki

Zakat yang kamu berikan juga bermanfaat untuk meningkatkan dan menyucikan kekayaan, lho. Sebab, orang kikir hidupnya akan dirundung kesulitan yang justru akan merugikan diri sendiri. Jika seseorang mengamalkan kekayaannya, dia akan terlindung dari penyakit dan Allah SWT akan meningkatkan kualitas hidupnya. Seperti yang disebutkan dalam Hadits: "Kekayaan tidak akan berkurang karena amal."

b. Meningkatkan Keberkahan Harta

Zakat merupakan kunci agar harta kita menjadi berkah. Harta yang berkah akan membuat pemiliknya selalu tenang. Harta berkah tidak selalu harus banyak, selalu ada ketika dibutuhkan, dan membuat pemiliknya selalu tenang."Rasul SAW bersabda: Harta tidak akan berkurang karena sedekah (zakat) dan tidaklah Allah menambah bagi hamba yang pemaaf kecuali kemuliaan dan tidak lah orang yang berlaku tawadhu' karena Allah melainkan Dia akan meninggikannya (HR. Muslim).

c. Memperluas Peredaran Harta

Jika seorang muslim ingin hartanya bertambah, buatlah harta itu menjadi berkah terlebih dahulu dengan mendapatkannya melalui cara yang halal, lalu membelanjakannya di jalan Allah dengan berzakat.Allah SWT berfirman, "Perumpamaan (nafkah yang dikeluarkan oleh) orang 
yang menafkahkan hartanya di jalan Allah adalah serupa dengan sebutir benih yang menumbuhkan tujuh bulir, pada tiap-tiap bulir: seratus biji. Allah melipat gandakan (ganjaran) bagi siapa yang Dia kehendaki. Dan Allah Maha Luas (kurnia-Nya) lagi Maha Mengetahui. (Qs. Al-Baqarah : 261).

4. Manfaat zakat dari segi sosial dan ekonomi

${ }^{7}$ Adapun tujuan zakat dalam kontek sosial ekonomi/muamalahadalahs sebagai berikut.

1) Pertama, zakat bertujuan untuk meningkatkan tarap hidup dan kesejahteraan masyarakat melalui pemerataan distribusi pendapatan yang diperoleh oleh orang kaya, untuk disalurkan kepada orang miskin melalui zakat, infak dan sedekah.

2) Kedua, pemberdayaan atas zakat, sebagai pemberdayaan atas zakat akan menjadi pendorong investasi secara langsung dan tidak langsung bagi suatu negara, karena dengan adanya zakat kekayaan yang ditabung akan segera diaktifkan atau diinvestasikan. Secara tidak langsung akan meningkatkan konsumsi terhadap barang dan jasa pokok sebagai akibat meningkatnya pendapatan orang-orang fakir-miskin, yang sekaligus akan mendorong produksi barang dan jasa menjadi meningkat pula.

3) Ketiga, menciptakan stabilitas ekonomi dalam tatanan kehidupan masyarakat yang akan mengangkat harkat dan martabat manusia. Baik itu di mata Allah terlebih lagi dimata manusia.

${ }^{7}$ Profitabilitas Studi and others, 'IBEF Journal Vol. 1 No. 1, Desember 2020', 1.1 (2020), 1-14. 


\section{BAB III}

\section{PENUTUP}

A. Kesimpulan

Zakat ditinjau dari segi bahasa memiliki banyak arti, yaitu al-barakatu yang mempunyai arti keberkahan, ath-thaharatu yang memiliki arti kesucian, al-namaa yang mempunyai arti pertumbuhan dan perkembangan, dan ashshalahu yang memiliki arti keberesan. Zakat merupakan salah satu ibadah yang wajib dilaksanakan oleh umat manusia yang beragama Islam sesuai dengan perintah Allah Swt. dengan tujuan dan maksud yang jelas serta hukum dan aturannya tercantum dalam Al-Quran dan Sunnah. Dari pengertian diatas, kita dapat mengetahui bahwa seseorang yang melakukan atau membayar zakat akan mendapatkan keberkahan dan kesuburan atas harta yang dimilikinya sesuai dengan aturan pembayaran zakat pada umumnya.

Manajemen adalah proses merencanakan, mengorganisasikan, pengarahan dan pengawasan usaha-usaha anggota organisasi dan penggunaan sumber daya sumber daya lainnya agar mencapai tujuan organisasi yang telah ditetapkan (Handoko, 1995). Jadi memimpin dan mengendalikan pekerjaan anggota organisasi dan menggunakan semua sumber daya organisasi untuk mencapai sasaran organisasi yang sudah ditetapkan merupakan merupakan tugas utama manajemen

Pengelolaan dan pemberdayaan zakat dibagi atas beberapa prinsip antara lain adalah sebagai berikut.

1. Prinsip keterbukaan

2. Prinsip Sukarela

3. Prinsip Keterpaduan

4. Prinsip Profesionalisme

5. Prinsip Kemandirian

Kita ketahui bahwa zakat adalah perbuatan atau perlakuan yang wajib dilakukan dan telah tercantum dalam beberapa ayat-ayat Al-Quran, ada beberapa manfaat jika kita melakukan atau mengeluarkan zakat, diantaranya adalah :

1. Manfaat zakat dari segi agama

a. Menyempurnakan iman 
b. Menambah ketaatan kepada Allah Swt

c. Membersihkan hati dan diri

d. Mencapai keimanan yang sempurna

2. Manfaat zakat dari segi sosial

a. Terbiasa Membantu Sesama

b. Menghilangkan Rasa Iri dan Prasangka

c. Merendahkan Hati

3. Manfaat zakat dari segi finansial

a. Meningkatkan Rezeki

b. Meningkatkan Keberkahan Harta

c. Memperluas Peredaran Harta

B. Saran

Sebagai umat muslim yang berada di negara hukum ini, kita diwajibkan untuk mematuhi aturan Allah dalam berbagai hal dan aturan pemerintah dalam beberapa hal. Seperti konteks zakat, infaq dan sedekah ini. Sebagai umat Islam yang bertakwa kita diwajibkan mengeluarkan zakat (mudzakki) kemudian diberikan kepada yang berhak menerima zakat (mustahik) menurut pandangan agama maupun menurut pemerintah.

Namun sayangnya pengetahuan masyarakat terhadap pengelolaan dan pemberdayaan zakat masih sangat minim sehingga banyak masyarakat yang kemudian lalai akan satu kewajiban ini.

Maka dari itu, seharusnya bagi para pengelola zakat harusnya memikirkan bagaimana caranya agar pengelolaan dana zakat tersebut terealisasikan dengan sebagaimana mestinya. Kami harapkan sebagai badan pengelola zakat hendaknya menyalurkan atau menginformasikan atau bahkan mengajarkan konsep maupun manfaat zakat dalam kehidupan dan masyarakat dapat berfikir bahwa dengan adanya pengetahuan mengelola dana zakat dengan baik, maka kehidupan dalam bermasyarakat akan semakin makmur dan sejahtera, sehingga kemiskinan dan kemelaratan yang masih memprihatinkan bisa kemudian teratasi karena adanya zakat. 


\section{DAFTAR PUSTAKA}

Andriyanto, Irsad, 'Pemberdayaan Zakat Dalam Meningkatkan Kesejahteraan Umat', Ziswaf, 1.2 (2014), 1-22

<http://journal.stainkudus.ac.id/index.php/Ziswaf/article/view/1485>

Anwar Sadat Harahap, and Dalyanto, 'Kajian Hukum Islam Terhadap Manfaat Zakat Dalam Pengembangan Ekonomi Masyarakat', Amaliah: Jurnal Pengabdian Kepada Masyarakat, 4.1 (2020), 99-105 <https://doi.org/10.32696/ajpkm.v4i1.402>

Ruslang, Ruslang, Samsul Samsul, and Mujetaba Mustafa, 'Komitmen Perusahaan Menjadi Muzakki', Al-Azhar Journal of Islamic Economics, 2.1 (2020), 25-35 <https://doi.org/10.37146/ajie.v2i1.26>

Studi, Profitabilitas, Pada Bank, Umum Syariah, and Di Indonesia, 'IBEF Journal Vol. 1 No. 1, Desember 2020', 1.1 (2020), 1-14

Sudrajat, Y, and A M I Jaya, 'Pemanfaatan Dana Zakat Oleh Badan Amil Zakat Nasional Dalam Pemberdayaan Masyarakat Miskin Di Kabupaten Bantaeng Provinsi ...', J-3P (Jurnal Pembangunan ..., 2019, 127-38 
<http://ejournal.ipdn.ac.id/JPDPP/article/view/857> 